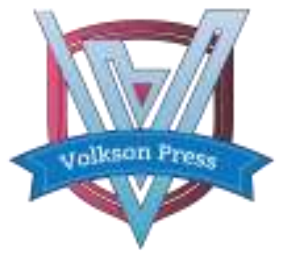

Economics, Finance and Statistics (EFS)

DOI : http://doi.org/10.26480/icefs.01.2018.60.65

\title{
CENTRAL BANKS' RESPONSES TO VIRTUAL CURRENCIES: AN OVERVIEW
}

\author{
Deimante Teresiene \\ Department of Finance, Faculty of Economics and Business Administration, Vilnius University, Sauletekio av. 9, Vilnius, Lithuania \\ Corresponding Author's E-mail: deimante.teresiene@ef.vu.It
}

This is an open access article distributed under the Creative Commons Attribution License, which permits unrestricted use, distribution, and reproduction in any medium, provided the original work is properly cited.

\section{ARTICLE DETAILS}

Article History:

Received 12 March 2018 Accepted 12 April 2018 Available online 15 May 2018

\section{ABSTRACT}

This article is focused on central banks' responses to virtual currencies. The view about virtual currencies is different in separate regions. Even in the same country we can see not similar opinions about cryptocurrencies among different authorities. The empirical research on virtual currencies disclosed that we do not have strict rules in central banking and that this aspect creates more risks in financial system. There are central banks which prohibit financial market participants to participate in activities associated with virtual currencies while others are considering their own virtual currency or thinking about virtual currencies in foreign reserves portfolio. The bank of Lithuania plans this year to issue a digital collector coin using blockchain or other equivalent technologies. So we can see very different central banks positions all over the world. After analyzing central banks positions in various regions the conclusion can be made that in some cases national banks can face even political pressure because of financial innovations.

\section{KEYWORDS}

bitcoin, central bank, virtual currency.

\section{INTRODUCTION}

Nowadays a lot of people are interested in virtual currencies. Investors are curious in exchange rate value growth and central banks are concerned about the possible impact of not regulated activity. Once Alan Greenspan, the former Federal Reserve Chairman, said "You have to really stretch your imagination to infer what the intrinsic value of Bitcoin is. I haven't been able to do it. Maybe somebody else can." So it is not easy to understand something which is called currency but do not have features of money. Usually we understand that money is medium of exchange, unit of account and store of value. We use money when we want to buy or sell goods and services. But with virtual currencies we can do that very limited. Virtual currencies are not used as a unit of account but we can use it as store of value with high exchange rate risk and sudden confidence shock. So according to broad understanding of term money we can say that now virtual currency is not money but maybe it could be in the future.

Usually we understand that fintech is related to innovations in financial sector and interpret that as a new era for financial services. An interest in fintech grows day by day. But with growing interest we see also increasing risks in financial systems. Managing director of the international monetary fund (IMF) has warned that central banks and financial services institutions need to pay closer attention to virtual currencies and that it is a possibility that cryptocurrencies could take the place of IMF's Special Drawing Rights (SDR).

This article tries to analyze the dynamic of central banks views on virtual currencies from the beginning of its appearance till the end of 2018 first quarter. This paper analysis not only central banks positions but tries to pay attention to other institutions' in the same country view about virtual currency possibilities.

This paper is organized as follows. Section II provides an analysis of the relevant literature on virtual currencies. Section III describes central banks views on virtual currencies and their risks on financial system in different regions. Section IV discloses conclusions.

\section{UNDERSTANDING OF VIRTUAL CURRENCIES AND CRYPTOCURRENCIES}

Usually virtual currency is understood as a new form of currency and a new payment technology because payments can be done directly between consumers and merchants and without any financial intermediary. Virtual currencies are attractive for consumers who value privacy and anonymity. But in order to use virtual currencies the user should know how to use technologies for payments. Companies giving the ability to pay by virtual currencies can avoid fees charged by banks and other financial intermediaries. Virtual currencies are quite attractive payment method for internet stores because they face relatively low implementation costs. Because of low transaction fees virtual currencies are attractive for customers also.

According to Financial Action Task Force (FATF), which is an independent inter-governmental body that develops and promotes policies to protect the global financial system against money laundering, terrorist financing and the financing of proliferation of weapons of mass destruction, virtual currencies have emerged and attracted investments in payment infrastructure [1]. FATF in the paper "Virtual currencies: Key Definitions and Potential AML/CFT Risks" described that virtual currencies offer an innovative, cheap and flexible method of payment. But together with these advantages virtual currencies have a set of risks and challenges to regulators around the world.

The European Banking Authority describes virtual currencies as a form of unregulated digital money, not issued or guaranteed by a central bank, which can act as means of payment.

As virtual currencies are quite a new field for scientific researches there is still a lack of papers analyzing different virtual currencies. Most papers concentrate on technical and computational aspects. Also, we can find articles analyzing Bitcoin as the most popular cryptocurrency but there is a lack of analysis dedicated for other type of virtual currencies. The paper of Dwyer (2015) give an overview of virtual currencies but the biggest 
In IMF staff discussion note "Virtual currencies and beyond: initial considerations" written by a group of researchers we can find that virtual currencies provide greater speed and efficiency in making payments and transfers - particularly across borders - and ultimately promoting financial inclusion [2]. The distributed ledger technology underlying some virtual currency schemes - an innovative decentralized means of keeping track of transactions in a large network - offers potential benefits that go far beyond virtual currencies themselves.

Virtual currencies face high volatility of its exchange rates because of behavior of speculators. Market speculators look at cryptocurrency as to a new mean of investment opportunity. More and more retail investors try to invest in virtual currencies hoping to get some yield form change in value.

The central bank for central banks - Bank for international settlements has said that policy makers can't ignore the growth of cryptocurrencies and will likely have to consider whether it makes sense for them to issue their own digital currencies at some point. "Bitcoin has gone from being an obscure curiosity to a household name," the BIS said in September. One option is a currency available to the public, with only the central bank able to issue units that would be directly convertible to cash and reserves. There might be a greater risk of bank runs, however, and commercial lenders might face a shortage of deposits. Privacy could also be a concern.

Agustin Carstens, the incoming head of the BIS, told Bloomberg that bitcoin deserves close scrutiny. "Anything that grows in price as fast as bitcoin has done it, without having a real clear understanding of what is behind it, should at least raise some eyebrows," he said.

Bitcoin is the famous virtual currency. If it so difficult to understand its exchange rate intrinsic value so what drives the market price to such highs. Bitcoin was launched in 2009 but it was not so popular at the beginning.

Bitcoin is not the only cryptocurrency. In figure 1 we can see that other cryptocurrencies can be even more volatile that bitcoin itself.

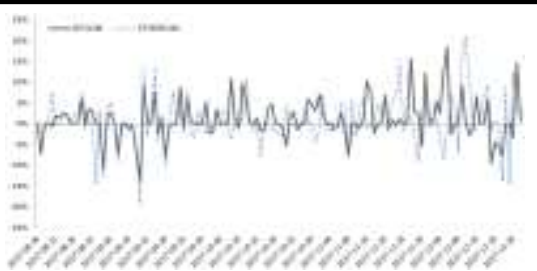

Figure 1: Bitcoin and Ethereum daily volaitility in percents

Source: Bloomberg

In the process of bitcoin use a user submits the account number which is called "public key" and a password named "private key". These keys are used for verification on the public transaction ledger which is widely known as "block chain". In other to verify that the transaction is real individuals which are called "miners" use computing power to solve a computationally intensive issue. They try to find "hash" of a "nonce". The individual who post the solution to the problem quicker is rewarded with a given number of bitcoin. In such way money creation process begins. In a study "Bitcoin as Money" described that the pre-programmed algorithm automatically adjusts the computational difficulty of verifying transactions in order to ensure that each transaction takes on average 10 minutes to verify [3]. The same algorithm is used for the increase of bitcoin supply, which is 21 million units to be mined by 2140 .

There are described three main advantages of bitcoins in the Federal Reserve Bank of Boston article written by a group of a researchers [3]. First advantage is that it is entirely decentralized system, second - it features pseudonymous accounts and third - it imposes no direct fees on transactions and promises the potential for lower transaction fees in general.

Analyzing virtual currencies we often think about financial technologies as a new era for finance sector. We even can see in some countries that if a central bank is against virtual currencies than it is a big trouble for financial technologies. In figure 1 we can see that in practice we have a lot of fields of financial innovations and that cryptocurrencies are only a small part from fintech segments belonging to payment systems.

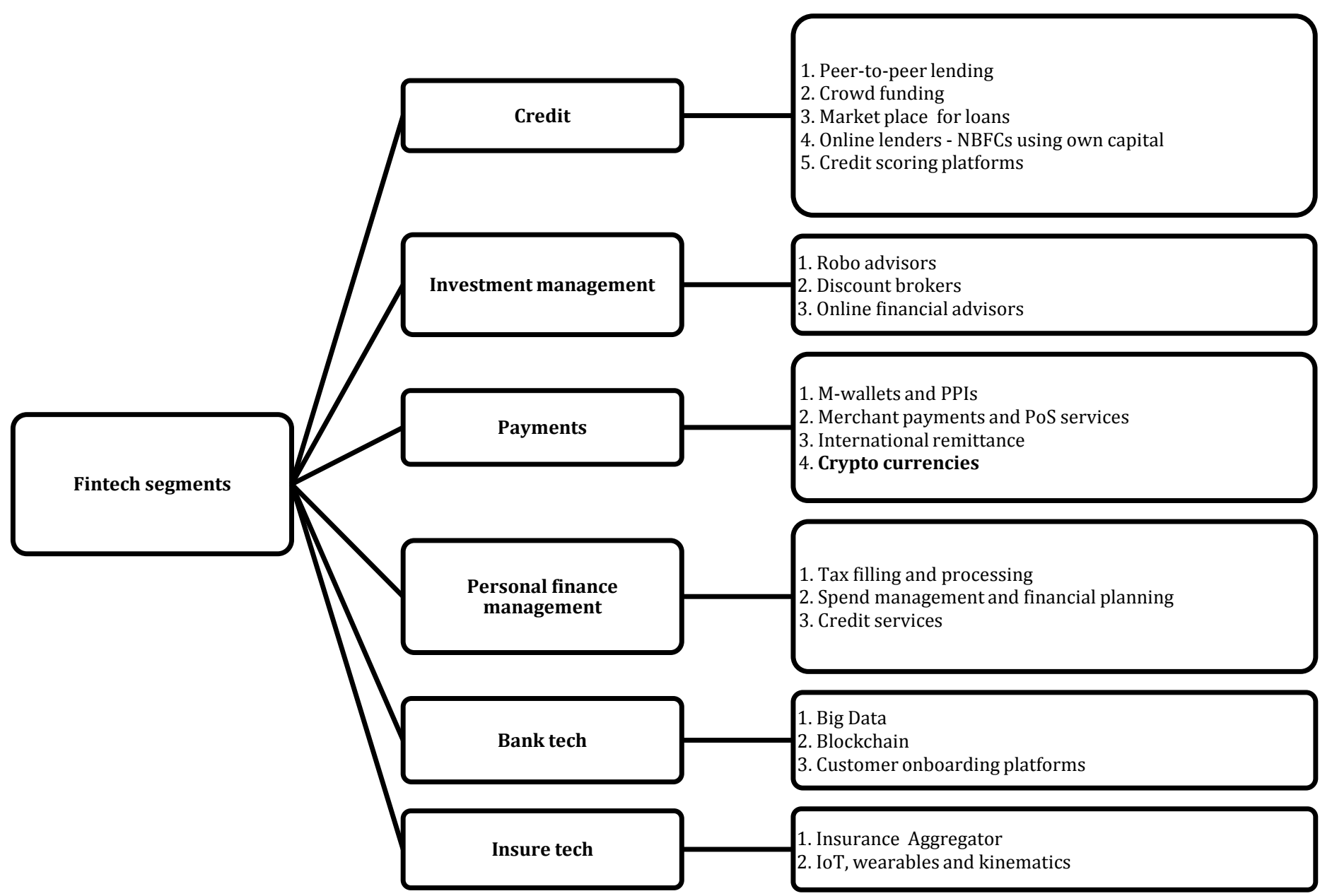

Figure 2: Fintech segments 
Source: Making India a Global Fintech Hub, Deloitte, Confederation of Indian Industry [4].

Virtual currencies and crypto currencies usually are understood as the same thing, but it is not a truth. There are various types of virtual currencies which do not have physical form. Cryptocurrencies are just one type of virtual currencies. So the main rule we should remember is that all cryptocurrencies are virtual currencies but not all virtual currencies are crypto currencies. Analyzing different countries experience we can see that usually virtual currencies are used as a synonym of cryptocurrency but such a view is not correct. IMF described the taxonomy of virtual currencies which is placed in figure 1 .

\section{Figure 4: Taxonomy of virtual currencies}

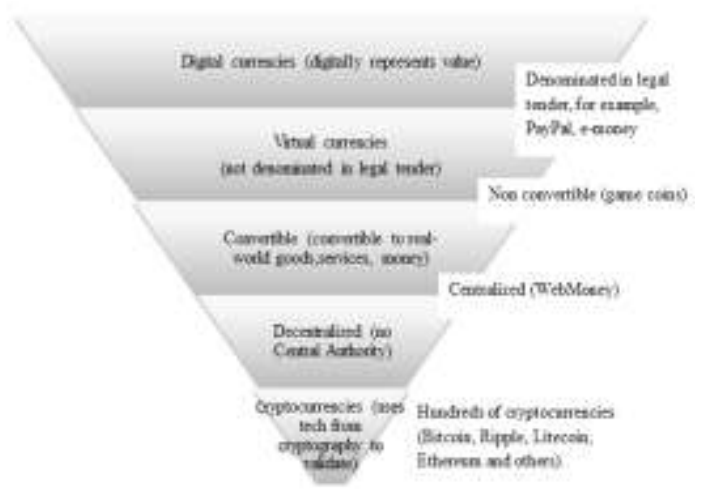

Source: IMF staff

Lately we can find central banks announcements that they are exploring or experimenting with distributed ledger technology and ideas of central bank crypto or digital currencies is attracting considerable attention. Bank of International Settlement published an article "Central bank cryptocurrencies" trying to look closer at this new alternative to cash.

\section{CENTRAL BANKS POSITIONS ON VIRTUAL CURRENCIES IN DIFFERENT REGIONS}

European central bank (ECB) in its paper "Virtual currency schemes" written in October 2012 tried to provide some clarity on virtual currencies [5]. ECB described that virtual currency is a type of unregulated, digital money, which is issued and usually controlled by its developers, and used and accepted among the members of a specific virtual community. In the same paper ECB described five risks: risk to price stability, risk to financial stability and to payment system stability, lack of regulation and reputational risk. But that paper was not something like a warning. It seemed more like discussion or a field for further analysis. Later ECB published another paper named "Virtual currency schemes - a further analysis" in February 2015 [6]. This report analyses virtual currency schemes further, with regard to their relevance for retail payment. Also in this paper ECB describes national responses to virtual currency schemes. In this article the author tries to continue ECB research and to look closer at different European central banks actions concerning virtual currencies.

In December 2013 the European Banking Authority (EBA) first issued a warning. EBA wrote that consumers may lose their money using exchange platforms. Informed that platforms were generally unregulated and money may be stolen from a digital wallet. Also EBA paid customers attention that the value of a virtual currency was unstable and that there was a danger that virtual currencies were used for unlawful activities. After that central banks started publishing warning with the references to EBA warning.

The three European Supervisory Authorities (ESAs), namely the European Banking Authority (EBA) for banks, the European Securities and Markets Authority (ESMA) for securities and the European Insurance and Occupational Pensions Authority (EIOPA) for insurance undertakings and pension funds in February 2018 issued a joint warning about virtual currencies. In the warning the institutions heightened risks associated with buying virtual currencies.

After analyzing different central banks main findings are described in table 1

Table 1: National banks respones to virtual currency

\begin{tabular}{|c|c|}
\hline $\begin{array}{l}\text { European } \\
\text { Central bank }\end{array}$ & $\begin{array}{l}\text { European Central Bank started the journey in virtual currency world in October of } 2012 \text { by presenting a } \\
\text { paper "Virtual currency scheme". Later in February of } 2015 \text { another paper "Virtual currency schemes - a } \\
\text { further analysis" appeared. In the latter paper } \\
\text { The European Central Bank has repeatedly warned about the dangers of investing in digital currencies. } \\
\text { Vice President Vitor Constancio said in September, } 2017 \text { that bitcoin isn't a currency, but a "tulip" - } \\
\text { alluding to the } 17 \text { th-century bubble in the Netherlands. Colleague Benoit Coeure has warned bitcoin's } \\
\text { unstable value and links to tax evasion and crime create major risks. President Mario Draghi said in } \\
\text { November the impact of digital currencies on the euro-area economy was limited and they posed no } \\
\text { threat to central banks' monopoly on money [5,6]. }\end{array}$ \\
\hline Austria & Financial Market Authority issued a warning against the use of virtual currencies. \\
\hline Belgium & $\begin{array}{l}\text { National bank of Belgium together with Financial services and markets authority on the } 14 \text { th of January } \\
2014 \text { announced a press release to be careful with virtual money, such as bitcoin. According to mentioned } \\
\text { institutions virtual currency is not legal tender or electronic money. These institutions informed that they } \\
\text { were monitoring developments concerning virtual currency units, such as Bitcoin and Litecoin. They } \\
\text { warned against the risks of virtual money }[7,8] \text {. }\end{array}$ \\
\hline Bulgaria & $\begin{array}{l}\text { There is no any inormation about bitcoins on the website of the Bulgarian Central Bank or on the local } \\
\text { Financial Supervisory Authority. Despite the fact the country is working on new payment systems } \\
\text { legislation. Also there were no any responses to virtual currency schemes in ECB paper, written in } 2015 \text {. } \\
\text { So it can be made a conclusion that there were no any strong restrictions from financial authorities. } \\
8 \text { December } 2017 \text { bankers have shut down all of Bulgaria's bitcoin exchanges. Bulgaria is a tech-savvy } \\
\text { country that has embranced bitcoin and the financial freedom it brings. Its legacy banking system seems } \\
\text { to have acted against the exchanges out of resentment and self-interest rather than due to orders issued } \\
\text { at state level. Bulgaria is the only country to be affected by banking clampdowns on bitcoin. }\end{array}$ \\
\hline Cyprus & $\begin{array}{l}\text { Published a warning on } 7 \text { th February 2014. The Centrtal Bank of Cyprus informed about the risks } \\
\text { associated with the purchase, holding or trading of virtual currencies (such as Bitcoin), which is not a } \\
\text { legal tender [9]. The central bank made a note that there was no guarantee or legal obligation to } \\
\text { reimburse at face value virtual currency owners, nor to reimburse them at any time. That the price of } \\
\text { virtual currencies was subject to high volatility. It may rose sharply or even fall to zero value. Acceptance } \\
\text { of virtual currencies by merchants was based on their discretion and may cease to exist at any point and } \\
\text { with no prior notice, in other words, any merchant may refuse to accept it for payments. Transactions in } \\
\text { virtual currencies were more liable to be misused for illegal activities [10]. } \\
\text { In } 2013 \text { the University of Nicosia started accepting Bitcoin for tuition and it was the world's first } \\
\text { accredited institution to accept cryptocurrency from its students. } \\
\text { 2nd November } 2017 \text { Cyprus Central Bank does not plan to increase the use of cryptocurrency in the } \\
\text { economic turnover, states the Supervision Division of the Central Bank of Cyprus to the CopPay inquiry. }\end{array}$ \\
\hline Czech Republic & $\begin{array}{l}\text { 10th February } 2014 \text { Bitcoins are not banknotes, coins, scriptural or electronic money. Published a } \\
\text { warning (reference to EBA warning). } \\
31 \text { th July } 2017 \text { Prague is home to a strong community of cryptocurrency supporters and users. The city } \\
\text { even has a café where customers can pay only in bitcoin. Many users of digital currency see it as a viable } \\
\text { alternative to the current monetary system. They even question whether institutions such as the Czech }\end{array}$ \\
\hline
\end{tabular}




\begin{tabular}{|c|c|}
\hline & $\begin{array}{l}\text { National Bank should be afraid of bitcoin and other independent currencies, and of their power to } \\
\text { marginalize traditional money. There really is no reason for banks to fear them. All of the alternative } \\
\text { currencies are negligible in terms of size and scope: electronic transactions using bitcoin worldwide } \\
\text { amount to only } 16 \% \text { of the electronic transactions conducted in the Czech koruna, a currency used by just } \\
10.5 \mathrm{~m} \text { people. }\end{array}$ \\
\hline Croatia & Bitcoin not legal tender, electronic money or foreign currency. But no published warning. \\
\hline Denmark & $\begin{array}{l}\text { According to central bank bitcoin is not a currency. Bitcoin does not have any real trading value compared } \\
\text { to gold and silver, and thus is more similar to glass beads. The central bank published a warning. } \\
\text { The Central Bank of Denmark expresses its fear regarding Bitcoin in } 23 \text { December, 2017. It seems it is } \\
\text { really a menace after all, for Bitcoin is again the target of criticism from traditional banking system. This } \\
\text { time, Danish central bank's director issued a warning to clients and investors to stay away from Satoshi's } \\
\text { coin. According to DR (a Denmark's broadcaster), director Lars Rohde stated that Bitcoin is a dangerous } \\
\text { asset, according his criteria, comparable to the tulip mania phenomenon, arguing that it is "like a bubble } \\
\text { out of control" that is unregulated by the authorities, and it is entire up to individuals and investors if they } \\
\text { have the possibility to lose their money. "[Investors] should not come complaining to us if it goes wrong," } \\
\text { Rhode said in an attempt to discredit the currency once again. He even labeled this cryptocurrency as an } \\
\text { alternative to casinos, stating that if people didn't like them, they could try gambling their money on } \\
\text { Bitcoin. } \\
\text { Denmark has backtracked somewhat from initial enthusiasm, with Deputy Governor Per Callesen } \\
\text { cautioning against central banks offering digital currencies directly to consumers. One argument is that } \\
\text { such direct access to central bank liquidity could contribute to runs on commercial banks in times of } \\
\text { crisis. }\end{array}$ \\
\hline Germany & $\begin{array}{l}19 \text { th August } 2013 \text { Germany's ministry of finance has formally recognized the digital currency Bitcoin as } \\
\text { a "unit of account" which can be used for private transactions - meaning that the ministry will now be } \\
\text { able to tax users or creators of the four-year-old virtual money [11]. Unit of account, not legal tender but } \\
\text { a financial instrument. Central bank published a warning. In a country where a lot of citizens still prefer } \\
\text { to pay in cash, the Bundesbank has been particularly wary of the emergence of bitcoin and other virtual } \\
\text { currencies. President Jens Weidmann in December described bitcoin's move as having a "speculative } \\
\text { character," though for regulators, "just because investors can lose money isn't a reason to get involved." } \\
\text { He said "the hurdle for regulatory action is quite high in my view." Board member Carl-Ludwig Thiele } \\
\text { said in September a shift of deposits into blockchain would disrupt banks' business models. At the same } \\
\text { time, the Bundesbank has been actively studying the application of the technology in payment systems. }\end{array}$ \\
\hline Estonia & $\begin{array}{l}\text { January 30, } 2014 \text { The central bank of Estonia urged consumers to steer clear of Bitcoin and similar virtual } \\
\text { currencies, warning such software could prove to be little more than a "Ponzi scheme." } \\
\text { September 7, } 2017 \text { ECB's Draghi rejects Estonia's virtual currency idea. The European Central Bank's } \\
\text { president criticized on Thursday a proposal by the Estonian government to launch a state-managed } \\
\text { digital currency, reaffirming instead that the euro was the only valid money in the euro area. no member } \\
\text { state can introduce its own currency." Draghi said in answer to a question during his regular press } \\
\text { conference. "The currency of the euro zone is the euro." The idea for the 'estcoin' came from Kaspar } \\
\text { Korjus, the head of Estonia's e-Residency project. The Tallinn government is now seeking feedback online. }\end{array}$ \\
\hline Finland & Not a currency and not a payment instrument. Central bank published a warning. \\
\hline France & $\begin{array}{l}\text { Central bank published a warning. } \\
\text { Bank of France Governor Francois Villeroy de Galhau said in June that French officials "advise great } \\
\text { caution with respect to bitcoin because there is no public institution behind it to provide confidence. In } \\
\text { history all examples of private currencies ended badly." Bitcoin even has a "dark side," he said, citing data } \\
\text { attacks and warning that people who use the cryptocurrency "do so at their own risk." }\end{array}$ \\
\hline Ireland & Published a warning. Reference to EBA warning. \\
\hline Italy & Virtual currencies a not considered legal tender. A w \\
\hline Greece & Published a warning. Reference to EBA warning. \\
\hline Hungary & Published a warning. \\
\hline Latvia & $\begin{array}{l}13 \text { February } 2014 \text { first warning. } \\
\text { Renewed } 31 \text { March } 2017 \text { The Bank of Latvia Announcement only in latvian. }\end{array}$ \\
\hline Lithuania & $\begin{array}{l}31 \text { January } 2014 \text { The Bank of Lithuania, with regard to the warning of the EBA of virtual currencies, } \\
\text { published its position. Warning the consumers of the potential risks on virtual currency. } \\
16 \text { July } 2014 \text { The Bank of Lithuania, with regard to the EBA opinion on virtual currency, made a } \\
\text { suggestion. Suggested that credit institutions, payment institutions and electronic money institutions } \\
\text { refrain from the purchase, storage or sale of virtual currency in order to reduce the risk arising from the } \\
\text { interaction of virtual currency schemes and regulated financial services, including the risks associated } \\
\text { with money laundering and other financial crimes, as well as the obscurity and uncertainty of the } \\
\text { financial capacity of market participants participating in virtual currency schemes. } \\
10 \text { October } 2017 \text { Bank of Lithuania presents the criteria and requirements, which should be observed by } \\
\text { financial market participants } 1 \text {.Financial markets participants providing financial services should not } \\
\text { participate in activities or provide services associated with virtual currencies [12]. } \\
\text { 2.Financial market participants should ensure actual separation of the financial services provision } \\
\text { activity from activities associated with virtual currencies, as well as ensure appropriate and not } \\
\text { misleading communication about the nature of services provided. } \\
\text { 3.In providing financial services to customers who are engaged in activities associated with virtual } \\
\text { currencies, financial market participants should ensure compliance with the requirements of money } \\
\text { laundering and terrorist financing prevention legislation, and take appropriate measures to manage the } \\
\text { risk of money laundering and/or terrorist financing. } \\
\text { In March } 2018 \text { the Bank of Lithuania announced about the plans to issue a one of a kind digital collector } \\
\text { coin using blockchain or other equivalent technologies. It will be a new step in numismatics [13]. }\end{array}$ \\
\hline Luxembou & Virtual currencies are not legal tender. Published a warning. \\
\hline Malta & $\begin{array}{l}\text { A warning published by Malta Financial Service Authority. And according to this organization virtual } \\
\text { currencies are not considered to be legal tender. }\end{array}$ \\
\hline Netherlands & $\begin{array}{l}3 \text { December } 2013 \text { Central bank published warning. } \\
\text { De Nederlandsche Bank (DNB) has special attention for the rise and growing popularity of virtual } \\
\text { currencies, including bitcoins and litecoins [14]. } \\
\text { The development of virtual currencies is gaining momentum. At present, they fall outside of the scope of } \\
\text { the Dutch Financial Supervision Act (Wet op het financieel toezicht or Wft). Consequently, DNB does not }\end{array}$ \\
\hline
\end{tabular}




\begin{tabular}{|c|c|}
\hline & $\begin{array}{l}\text { supervise virtual currencies or enterprises trading in them. DNB advises consumers to be aware of this } \\
\text { and the potential risks of buying bitcoins or other virtual currencies. The exchange rates are volatile and } \\
\text { there is no central issuing institution that consumers can hold liable should the need arise. Moreover, the } \\
\text { deposit guarantee scheme does not apply. } \\
\text { The Dutch have been among the most daring when it comes to experimenting with digital currencies. Two } \\
\text { years ago the central bank created its own cryptocurrency called DNBcoin -- for internal circulation only } \\
\text {-- to better understand how it works. Presenting the results in 2016, Ron Berndsen, who was in charge of } \\
\text { the project, said blockchain may be "naturally applicable" in the settlement of complex financial } \\
\text { transactions [15]. }\end{array}$ \\
\hline Poland & Published a warning. Not legal tender. \\
\hline Portugal & Published a warning. \\
\hline Slovakia & Central bank published a warning. \\
\hline Slovenia & $\begin{array}{l}\text { Not currency and not a payment instrument Bitcoin could fall within the scope of the Prevention of Money } \\
\text { Laundering and Terrorist Financing Act. Central bank publised a warning with reference to EBA warning. }\end{array}$ \\
\hline Spain & $\begin{array}{l}\text { Virtual currencies are not considered legal currency, since they are not issued by the government's } \\
\text { monetary authority. Central bank published informative note but not warning. }\end{array}$ \\
\hline Sweden & $\begin{array}{l}\text { Asset and not a currency. Central bank published a warning. } \\
\text { Sweden's Riksbank, the world's oldest central bank, is probing options including a digital register-based } \\
\text { e-krona, with balances in central-database accounts or with values stored in an app or on a card. The bank } \\
\text { says the introduction of an e-krona poses "no major obstacles" to monetary policy. }\end{array}$ \\
\hline United Kingdom & $\begin{array}{l}\text { Act as money only to a limited extent and only for relatively few people. Published a warning with } \\
\text { reference to EBA warning. } \\
\text { Bank of England Governor Mark Carney has cited cryptocurrencies as part of a potential "revolution" in } \\
\text { finance. The central bank started a financial technology accelerator in 2016, a Silicon Valley practice to } \\
\text { incubate young companies. Carney says technology based on blockchain, the distributed accounting } \\
\text { database, shows "great promise" in enabling central banks to strengthen their defenses against cyber } \\
\text { attack and overhaul the way payments are made between institutions and consumers. He has } \\
\text { nevertheless cautioned the BOE is still a long way from creating a digital version of sterling [16]. }\end{array}$ \\
\hline China & $\begin{array}{l}\text { December } 2013 \text { The Chinese central bank has warned the country's financial institutions not to trade in } \\
\text { bitcoin, saying that the digital currency doesn't have "real meaning" and lacks legal protections. The bank } \\
\text { also identified money laundering and other illegal uses of the currency as areas of concern. } \\
\text { April } 2014 \text { The People's Bank of China is threatening action from } 15 \text { April against payment processors } \\
\text { who enable bitcoin sales. In late March, reports broke that the Chinese government will begin penalizing } \\
\text { any bank transacting with bitcoin exchanges after 15th April [17]. } \\
\text { December 04, } 2017 \text { China once dominated the bitcoin markets, accounting for over } 90 \% \text { of global trading. } \\
\text { But in September, its central bank banned initial coin offerings (ICOs) and stopped cryptocurrency } \\
\text { exchanges from serving local customers. Looking back at the crackdowns, Pan Gongsheng, a deputy } \\
\text { governor of the People's Bank of China, believes Beijing made the right decisions [18]. }\end{array}$ \\
\hline Thailand & $\begin{array}{l}3 \text { July } 2017 \text { The Bank of Thailand has been ordered by Thailand's Deputy Prime Minister to look } \\
\text { closer at bitcoin and relax its strict rules which hinder fintech innovation. In response to the Deputy } \\
\text { Prime Minister's order, the BOT governor, Veerathai Santiprabhob, said that there are many factors to } \\
\text { consider in studying bitcoin. The bank will also determine if it could be used to pay off debts legally, } \\
\text { according to the Nation TV [19]. The BOT governor reiterated that the bank has not adopted bitcoin as a } \\
\text { legal currency or a method of payment like Japan has. He also noted concerns over its volatility as well as } \\
\text { the lack of public understanding on the subject. The bank needs to carefully examine the development of } \\
\text { bitcoin further to determine how useful it is, and weigh between its benefits and risks, he detailed [20]. }\end{array}$ \\
\hline Japan & April 2016 Japan Officially Recognizes Bitcoin and Digital Currencies as Money. \\
\hline India & $\begin{array}{l}\text { December } 2013 \text { The Reserve Bank of India published a warning to the public against the use of virtual } \\
\text { currencies. The Reserve Bank of India has today cautioned the users, holders and traders of Virtual } \\
\text { currencies (VCs), including Bitcoins, about the potential financial, operational, legal, customer protection } \\
\text { and security related risks that they are exposing themselves to. The Reserve Bank has mentioned that it } \\
\text { has been looking at the developments relating to certain electronic records claimed to be "Decentralized } \\
\text { Digital Currency" or "Virtual Currency" (VCs), such as, Bitcoins, litecoins, bbqcoins, dogecoins etc., their } \\
\text { usage or trading in the country and the various media reports in this regard. The creation, trading or } \\
\text { usage of VCs including Bitcoins, as a medium for payment are not authorized by any central bank or } \\
\text { monetary authority. No regulatory approvals, registration or authorization is stated to have been } \\
\text { obtained by the entities concerned for carrying on such activities. As such, they may pose several risks to } \\
\text { their users. } \\
5 \text { December } 2017 \text { The Reserve Bank of India issued a new warning on cryptocurrencies [21-24]. } \\
1 \text { February } 2017 \text { The Reserve Bank of India clarified that it has not given any license/authorization to } \\
\text { any entity to operate such schemes or deal with Bitcoin or any other virtual currency. The Reserve Bank } \\
\text { of India had cautioned the users, holders and traders of Virtual Currencies (VCs), including Bitcoins, } \\
\text { about the potential financial, operational, legal, customer protection and security related risks that they } \\
\text { are exposing themselves to, vide its press release dated December 24, 2013. } \\
\text { The Reserve Bank of India advises that it has not given any licence / authorisation to any entity / } \\
\text { company to operate such schemes or deal with Bitcoin or any virtual currency. As such, any user, } \\
\text { holder, investor, trader, etc. dealing with Virtual Currencies will be doing so at their own risk [25-29]. }\end{array}$ \\
\hline
\end{tabular}

\section{CONCLUSIONS}

After looking at different central banks policies and analyzing various kind of literature in virtual currencies I can make a conclusion that there is a misunderstanding between virtual currencies and cryptocurrencies. Central banks in their warnings and analysis about virtual currencies should pay more attention trying to disclose these differences.

The other very important aspect is the fact that central banks in their warnings writing about virtual currencies concentrates only on bitcoin and some of them mentions also litecoin. To my opinion central banks should inform about all possible cryptocurrencies in order to protect customers' interests.

Analyzing different central banks we see various opinions and positions on virtual currencies. I think that central banks should have one strict opinion about cryptocurrencies. And if it's a part of payment system central banks should be more active in regulating this field. If cryptocurrencies are bad and dangerous thing then central banks should take strict position and forbid such instruments or activity with them. And if they see any good and innovative things in cryptocurrencies they should take regulative position and let cryptocurrencies to be as one of alternatives in payment system. Because now we see different views: China banned the use of 
cryptocurrencies (shut down digital currency exchanges), we see freedom for bitcoin in Japan and no real position in other countries. I think that warning is not a position if we see such an understanding that bitcoin is a unit of account (Germany case) or central banks ideas to have their own virtual currency (Estonia, Sweden and other ideas of central bank cryptocurrencies).

And the last aspect which should be stressed is political pressure to legislate cryptocurrencies as a tool of financial innovations. The strangest suggestion to my opinion was from Australian parliament to include bitcoins into foreign reserve portfolio.

This paper encourages analyzing central banks positions on initial coin offerings (ICO) and legal financial instruments which are related to cryptocurrencies.

\section{ABOUT THE AUTHORS}

Deimante Teresiene, $\mathrm{PhD}$ is an associated professor at Vilnius University in Lithuania. Deimante Teresiene currently is working at the Bank of Lithuania but this article and views of the author do not represent the Bank of Lithuania position.

\section{REFERENCES}

[1] Financial action task force. 2014. Virtual Currencies Key Definitions and Potential AML/CFT Risks. FATF Report.

[2] Lam, E. 2018. What the World's Central Banks Are Saying About Bitcoin.

[3] Lo, S., Wang, J.C. 2014. Bitcoin as Money.

[4] Latvijas, Ba. 2014. Par bitcoin.

[5] European Central Bank. 2012. Virtual Currency Schemes.

[6] European Central Bank. 2015. Virtual currency schemes - a further analysis.

[7] National Bank of Belgium. 2014. Financial services and markets authority. Be careful with virtual money, such as bitcoin. Press Release.

[8] Bech, M., Garratt, R. 2017. Central bank cryptocurrencies. BIS Quarterly Review.

[9] 2017. Cyprus Central Bank will not increase use of cryptocurrency in the country.

[10] Dyson, B., Hodgson, G. 2016. Why central banks should start issuing electronic money. Positive Money.

[11] Arthur, C. 2013. Bitcoin now "unit of account" in Germany.
[12] Bank of Lithuania. 2018. Lithuania's central bank to issue the world's first digital collector coin.

[13] Bank of Lithuania. 2017. Bank of Lithuania announces its position on virtual currencies and ICO.

[14] De Nederlandsche Bank. 2013. Consumers should be aware of the risks of virtual currencies.

[15] Canepa, F. 2017. ECB's Draghi rejects Estonia's virtual currency idea Central bank of Cyprus. 2014. Attention to the risks associated with virtual currencies.

[16] Barrdear, J., Kumhof, M. 2016. The macroeconomics of central bank issued digital currencies. Staff working paper 605. Bank of England.

[17] Hern, A. 2014. Chinese bitcoin exchange closes deposits after central bank clampdown. The Guardian.

[18] Hern, A. 2013. Bitcoin price tumbles after warning from Chinese central bank. The Guardian.

[19] Helms, K. 2017. Bank of Thailand ordered to relax strict rules and study bitcoin.

[20] Hampl, M. 2017. Don't be afraid of bitcoin.

[21] Prasad, A. 2013. RBI cautions users of Virtual Currencies against Risks. Reserve bank of Indian.

[22] Gupta, S., Lauppe, P., Ravishankar, S. 2017. Fedcoin: A blockchainbacked central bank cryptocurrency.

[23] Kattoor, J.J. 2017. Reserve Bank cautions regarding risk of virtual currencies including Bitcoins.

[24] Kattoor, J.J. 2017. RBI cautions users of Virtual Currencies. Reserve bank of India

[25] 2017. Making India a Global Fintech Hub, Deloitte, Confederation of Indian Industry.

[26] Dong, H., Habermeier, K., Leckow, R., Haksar, V., Almeida, Y., Kashima, M. 2016. Virtual Currencies and Beyond : Initial Considerations. IMF Staff Discussion Note.

[27] Huang, Z.P. 2017. China's central bank believes bitcoin will die Quartz.

[28] Sedgwick, K. 2017. Bankers have shut down all of Bulgaria's bitcoin exchanges.

[29] Bolt, W., van Oordt, M.R.C. 2016. On the Value of Virtual Currencies. Staff Working paper. Bank of Canada. 